
Mr Miroslav Glišić, kapetan I klase, Institut ratne veštine Beograd

\section{STANDARDIZACIJA MATERIJALNIH
SREDSTAVA U SEVERNOATLANTSKOM \\ STANDARDIZACIJA MATERIJALNIH
SREDSTAVA U SEVERNOATLANTSKOM SAVEZU}

UDC: $006.42: 623: 327.51(1-15)$

Rezime:

U radu je prikazan proces standardizacije materijalnih sredstava u Severnoatlantskom savezu kroz sagledavanje njegovog mesta i uloge u okviru zajedničke standardizacije, koja se realizuje radi dostizanja interoperabilnosti između vojnih snaga zemalja uključenih u evroatlantske integracije.

Ključne reči: standardizacija, interoperabilnost, Konferencija direktora za nacionalno naoružanje, Agencija NATO za konsultacije, komandovanje i kontrolu, Severnoatlantski savez.

\title{
MATERIEL STANDARDIZATION IN NORTH ATLANTIC TREATY ORGANISATION
}

Summary:

This paper presents a process of materiel standardization in the North Atlantic Treaty Organization through analysis of its place and role in common standardization process that should achieve interoperability between allied forces.

Key words: standardizacion, interoperability, North Atlantic Treaty Organization, National Armaments Directors Conference, NATO Consultation, Command and Control Agency.

\section{Uvod}

Opredeljenje državne zajednice Srbija i Crna Gora za pristupanje evroatlantskim integracijama nameće potrebu za dostizanjem interoperabilnosti njenih vojnih snaga sa snagama Severnoatlantskog saveza - NATO. Proces zajedničke standardizacije unutar NATO predstavlja osnovno sredstvo dostizanja interoperabilnosti. Ona se realizuje na operativnom, materijalnom i administrativnom polju. Za standardizaciju materijalnih sredstava odgovorna je Konferencija direktora za nacionalno naoružanje i Agencija NATO za konsultacije, komandovanje $i$ kontrolu. Navedene organizacije u okviru svojih organizacionih celina formiraju privremene radne grupe za izradu novih i reviziju postojećih dokumenata o standardizaciji. U radu tih grupa učestvuju eksperti iz zemalja članica NATO i iz zemalja partnera. Po pristupanju programu Partnerstvo za mir državna zajednica Srbija i Crna Gora steći će mogućnost da učestvuje u radnim grupama za izradu dokumenata o standardizaciji.

\section{Definisanje standardizacije i inter- operabilnosti u Severnoatlantskom savezu}

NATO rečnik termina i definicija zajedničku standardizaciju unutar Saveza definiše kao: ,...razvoj i implementaciju koncepata, doktrina, procedura i planova koji- 
ma se obezbeđuje i održava potreban nivo kompatibilnosti, zamenljivosti ili zajedništva na operativnom, materijalnom i administrativnom polju radi dostizanja interoperabilnosti“" [1]. Dakle, zajednička standardizacija unutar NATO osnovno je sredstvo dostizanja interoperabilnosti, koja se definiše kao: ,....sposobnost snaga NATO i kada je potrebno, snaga zemalja partnera i ostalih ne-NATO zemalja za zajedničkom obukom, vežbama i uspešnim radom u realizaciji poverenih misija i zadataka“" [1]. Dostizanje interoperabilnosti realizuje se na operativnom, materijalnom i administrativnom polju. Posebno važni objekti dostizanja interoperabilnosti su vojne procedure i postupci, borbena tehnika, sistemi za konsultacije, komandovanje i kontrolu, logistika i terminologija.

\section{Zajednička standardizacija unu- tar Severnoatlantskog saveza}

Osnovna uloga procesa standardizacije u NATO je razvoj i implementacija dokumenata o standardizaciji radi dostizanja interoperabilnosti. Dokumenta o standardizaciji predstavljaju ugovori o standardizaciji (Standardization Agreements - STANAGS) i savezničke publikacije o standardizaciji (Allied Publications - APs).

Ugovori o standardizaciji definišu se kao ,zapis o dogovoru između nekoliko ili svih država članica kojim usvajaju istu ili sličnu vojnu opremu, municiju, sisteme snabdevanja i skladištenja, kao i operativne, logističke i administrativne procedure. Takođe, prihvatanje Savezničke publikacije o standardizaciji od strane svih država, a koju je objavila Agencija NATO za standardizaciju, može se smatrati ugovorom o standardizaci- ji“ [1]. Saveznička publikacija o standardizaciji je zvaničan dokument o standardizaciji koji neke ili sve članice NATO saglasno koriste kao zajednički punovažni dokument. Publikacija je namenjena za direktnu upotrebu korisnicima u ministarstvima odbrane i vojskama saveznika i partnera, tako da nije neophodno da se te informacije objavljuju posebno u svakoj državi. Postoje tri vrste savezničkih publikacija o standardizaciji [2]:

- savezničke publikacije o standardizaciji koje sadrže samo činjenične informacije i ne zahtevaju postojanje odgovarajućeg ugovora o standardizaciji;

- savezničke publikacije o standardizaciji koje upućuju na radnje koje treba da se preduzmu u određenim situacijama. Ova vrsta publikacija zahteva odobrenje države članice u obliku ratifikacije odgovarajućeg ugovora o standardizaciji;

- savezničke publikacije o standardizaciji koje su kombinacija prethodne dve, odnosno činjeničnih informacija (koje ne zahtevaju ratifikaciju) i zahteva - instrukcija koje su direktivne po prirodi i zahtevaju odobrenje pojedinačne države u vidu ratifikacije odgovarajućeg ugovora o standardizaciji. Nadležni organi imaju zadatak da obezbede da činjenične informacije budu jasno identifikovane, obično u vidu dodatka u posebnom aneksu savezničke publikacije o standardizaciji.

Dokumenta o standardizaciji razvijaju se i implementiraju kroz tri potfunkcije standardizacije: operativnu; materijalnu i adminstrativnu [3].

Operativna standardizacija razvija i implementira dokumenta koja se tiču budućih i/ili aktuelnih vojnih postupaka i procedura. Ona mogu biti primenjena za usaglašavanje pitanja koja se odnose na koncepte, 
doktrine, taktiku, logistiku, vežbe, organizaciju, izveštaje, obrasce, planove i šeme.

Standardizacija materijalnih sredstava razvija i implementira dokumenta koja se tiču karakteristika budućih i/ili sadašnjih materijalnih sredstava, kao što su sistemi za komandovanje, kontrolu i komunikaciju, sistemi naoružanja, razni podsistemi, komponente, rezervni delovi i potrošni materijal (uključujući municiju i gorivo).

Administrativna standardizacija razvija i implementira dokumenta koja se prvenstveno odnose na terminologiju koja se primenjuje na operativnom i na materijalnom polju. Pored toga, administrativna standardizacija razvija i implementira dokumenta koja olakšavaju NATO administraciju u oblastima koje nemaju direktnu vojnu primenu (npr. izveštavanje o ekonomskim statistikama, izrada strategijskih pregleda odbrane i slično).

Nivoi standardizacije definisani su na sledeći način [1]:

- kompatibilnost - prikladnost zajedničke upotrebe proizvoda, procesa ili usluga pod određenim uslovima, radi dostizanja relevantnih zahteva bez izazivanja neprihvatljivih interakcija;

- zamenljivost - mogućnost da se jedan proizvod, proces ili usluga koristi umesto nekog drugog kako bi se ispunili isti zahtevi;

- zajedništvo - stanje koje se postiže kada se koriste iste doktrine, procedure ili oprema.

\section{Stručni organi standardizacije materijalnih sredstava $u$ Severnoatlantskom savezu}

Struktura sistema za zajedničku standardizaciju unutar NATO sastoji se od elemenata prikazanih na slici 1 [3].
Severnoatlantski savet je najviše telo NATO, u kojem su države članice predstavljene na ambasadorskom nivou. Odgovoran je za sveukupnu politiku NATO, pa samim tim i za proces zajedničke standardizacije.

Vojni komitet odgovoran je Severnoatlantskom savetu, Komitetu za planiranje odbrane i Grupi za nuklearno planiranje za realizaciju svih vojnih poslova u NATO. Direktno ili preko svojih potčinjenih strategijskih komandi (Saveznička komanda za operacije i Saveznička komanda za transformaciju) učestvuje u identifikaciji standardizacionih zahteva nedostataka za potrebe njihovog rada.

Organizacija NATO za standardizaciju sastavljena je od Komiteta NATO za standardizaciju, Štabne grupe NATO za standardizaciju i Agencije NATO za standardizaciju. Ona predstavlja osnovni subjekat standardizacije u Savezu i zadužena je za poboljšanje koordinacije i obezbeđenje realizacije aktivnosti koje se odnose na standardizaciju.

Agencija NATO za standardizaciju, Viša konferencija za NATO logistiku, Konferencija direktora za nacionalno naoružanje i Komisija NATO za konsultacije, komandovanje i kontrolu zaduženi su, preko svojih potčinjenih tela, za razvoj i implementaciju dokumenata o standardizaciji unutar njihovih nadležnosti. Ta tela razvijaju nova i prilagođavaju stara dokumenta o standardizaciji. Agencija NATO za standardizaciju i Viša konferencija za NATO logistiku odgovorne su za potfunkciju operativne standardizacije, Konferencija direktora za nacionalno naoružanje za potfunkciju materijalne standardizacije, a Agencija NATO za konsultacije, komandovanje i kontrolu za 


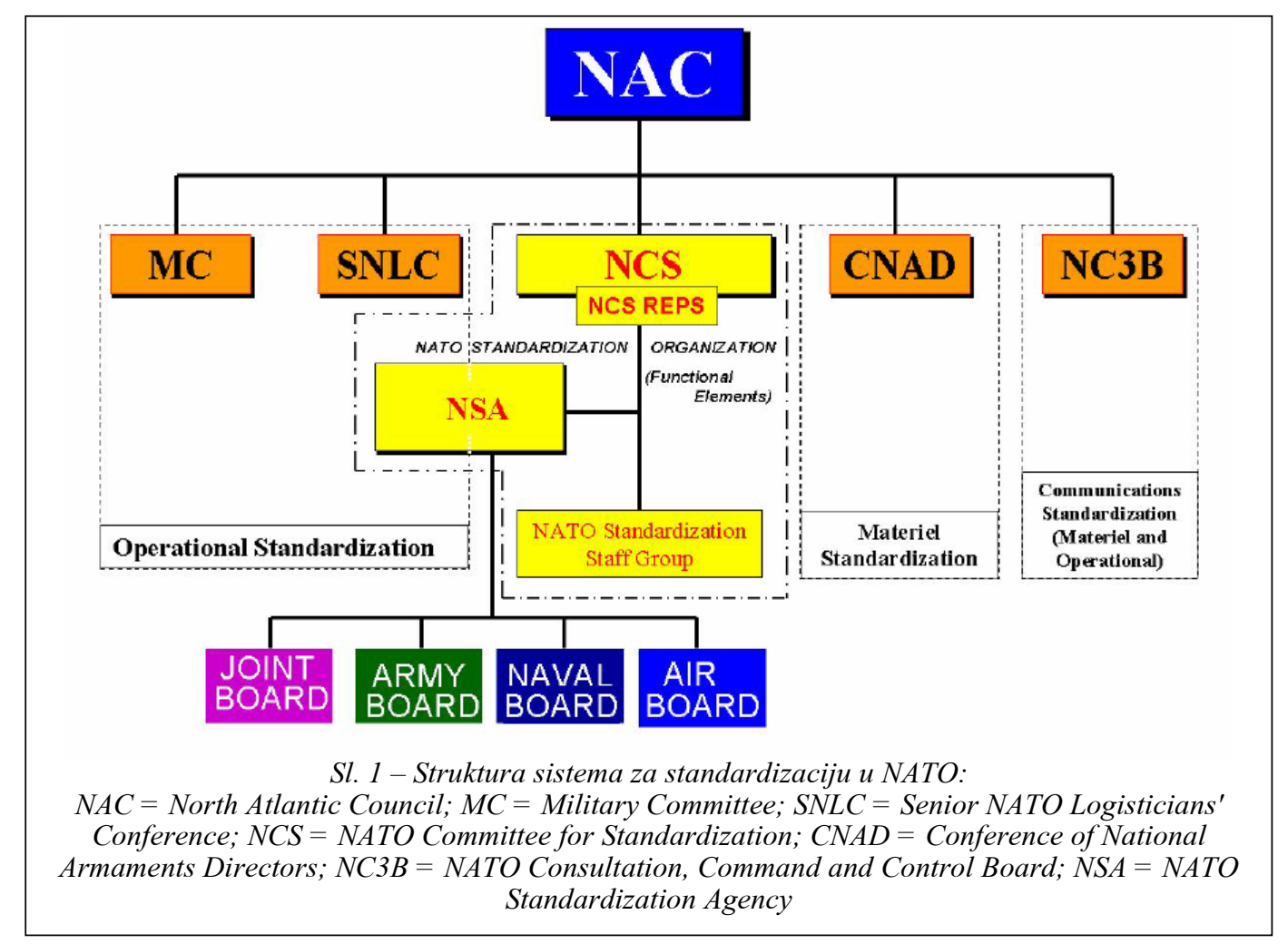

potfunkcije materijalne i operativne standardizacije u oblasti komunikacija. Administrativnu standardizaciju realizuju sve navedene organizacione celine u svojim oblastima.

Operativnu, materijalnu i administrativnu standardizaciju prikazani sistem realizuje kroz [4]:

- identifikaciju standardizacionih zahteva - nedostataka, koju realizuju Vojni komitet sa strategijskim komandama, članice NATO i zemlje partneri (pristup odozgo na dole) i privremeno formirane specijalizovane ekspertske grupe članica NATO i zemalja partnera, koje rade $u$ okviru organizacionih tela sistema za standardizaciju (pristup odozdo na gore). Kroz identifikaciju standardizacionih zahteva - nedostataka određuju se oblasti u kojima treba dostići interoperabilnost primenom procesa standardizacije;

- formulisanje i usaglašavanje prioriteta ciljeva standardizacije u odnosu na već uočene standardizacione zahteve nedostatke;

- razvoj novih i prilagođavanje starih dokumenata o standardizaciji. S obzirom na širok spektar oblasti za koje se ta dokumenta propisuju, navedenu aktivnost realizuju sve organizacione celine sistema za standardizaciju u NATO;

- ratifikovanje dokumenata o standardizaciji od svake države ponaosob. Imajući u vidu da se funkcija standardizacije realizuje na dobrovoljnoj osnovi, države članice mogu ispoljiti rezervu u odnosu na predloženi dokument o standardizaciji. Zemlje partneri ne učestvuju 
u procesu ratifikacije dokumenata o standardizaciji, već ta dokumenta dobrovoljno usvajaju radi implementacije kroz instrumente partnerstva;

- objavljivanje dokumenata o standardizaciji, što se realizuje nakon njihove ratifikacije, a u nadležnosti je predsedavajućeg Agencije NATO za standardizaciju;

- implementiranje usaglašenih dokumenata o standardizaciji, što je u nadležnosti članica NATO i zemalja partnera. Međutim, pomoć državama članicama i zemljama partnerima pri implementaciji dokumenata o standardizaciji mogu pružiti organizacione celine sistema za standardizaciju u NATO;

- verifikovanje implementiranih dokumenata, čime se implementirana dokumenta o standardizaciji prihvataju, prilagođavaju ili povlače iz upotrebe.

Realizacija navedenih aktivnosti omogućava dostizanje i održavanje nivoa kompatibilnosti, zamenljivosti i zajedništva radi obezbeđenja interoperabilnosti. Operativna i administrativna standardizacija obezbeđuju prvenstveno nivo zajedništva, dok standardizacija materijalnih sredstava obezbeđuje sva tri zadata nivoa. Kompatibilnost se, prvenstveno, odnosi na komandno-informacione sisteme i borbenu tehniku, zamenljivost streljačke i artiljerijske municije, goriva i sistema za snabdevanje i servisiranje multinacionalnih snaga, a zajedništvo na doktrine i procedure, kao i na zajednički razvoj ratne tehnike (oklopna borbena vozila, avioni, brodovi i sistemi naoružanja) [4].

Uporedo sa donošenjem odluka o stvaranju unapređenog i operativnijeg partnerstva, doneta je odluka i o aktivnom učešću partnera u procesu standardi- zacije u NATO čime im je omogućeno da unapređuju svoju interoperabilnost $u$ odnosu na zemlje članice [5]. U stvari, učešćem u radnim telima prikazanih organizacija za standardizaciju, partneri od samog početka učestvuju u razvoju dokumenata o standardizaciji koje će radi dostizanja interoperabilnosti kroz instrumente partnerstva kasnije implementirati na svoje snage.

Kao što je već prikazano za potfunkciju standardizacije materijalnih sredstava, unutar NATO odgovorna je Konferencija direktora za nacionalno naoružanje i Agencija NATO za konsultacije, komandovanje i kontrolu. Konferencija direktora za nacionalno naoružanje za sada u procesu zajedničke standardizacije učestvuje sa $29 \%$, odnosno od postojećih 1248 usvojila je 358 ugovora o standardizaciji, a Agencija NATO za konsultacije, komandovanje i kontrolu sa $3 \%$ jer je razvila ukupno 34 ugovora.

Konferencija direktora za nacionalno naoružanje (Conference of National Armaments Directors - CNAD, AC/259) odgovorna je za usmerenje i koordinaciju zajedničkih aktivnosti unutar NATO koje se odnose na saradnju u istraživanju, razvoju i proizvodnji naoružanja i vojne opreme. Ona je glavni nosilac standardizacije materijalnih sredstava. Konferencija se sastaje na plenarnim sednicama dva puta godišnje, kada predsedava generalni sekretar NATO, dok je pomoćnik generalnog sekretara za podršku odbrane stalni predsedavajući. Konferencija okuplja visoke zvaničnike odgovorne za opremanje naoružanjem i vojnom opremom oružanih snaga država članica NATO i zemalja partnera, predstavnike Voj- 


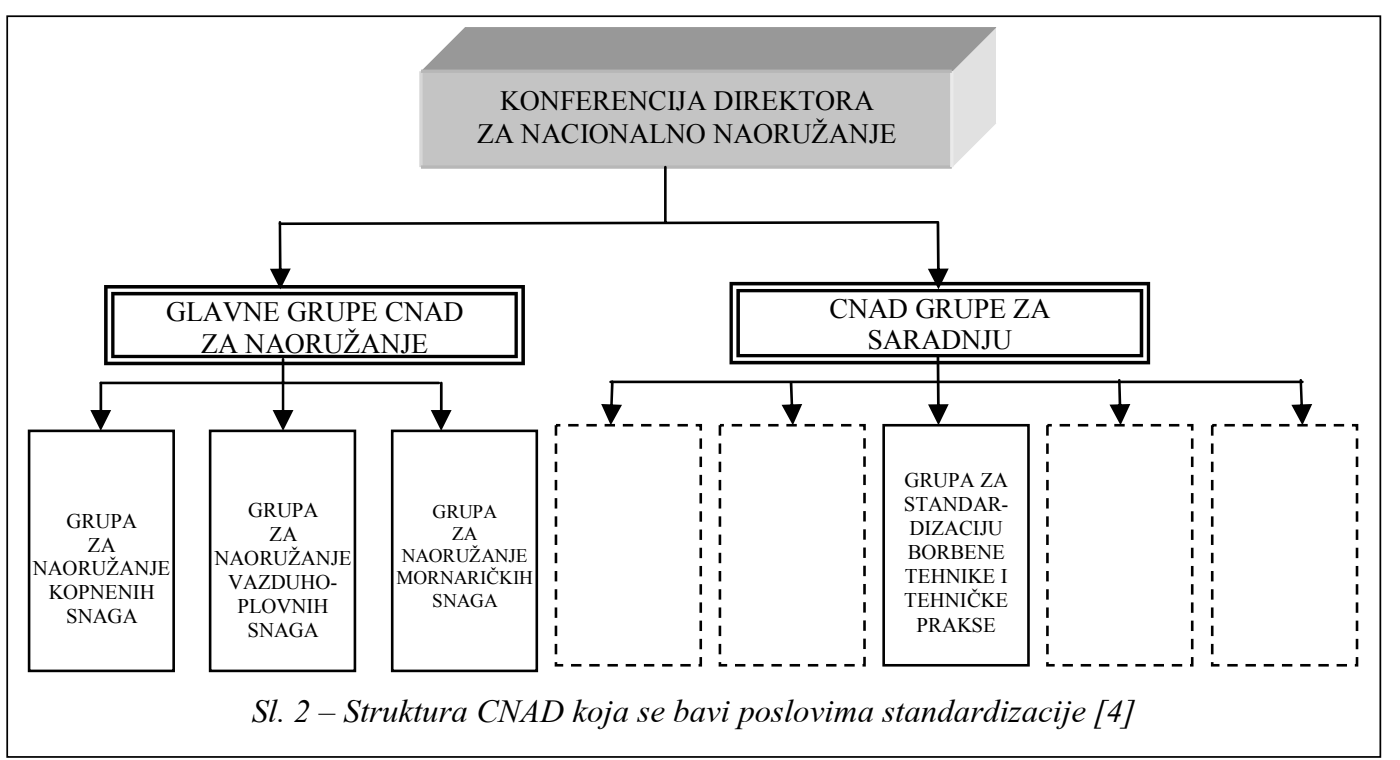

nog komiteta i strategijskih komandi NATO, predstavnike privremeno formiranih radnih grupa CNAD i druge civilne i vojne vlasti odgovorne za različite aspekte proizvodne logistike [4]. Navedenu ulogu Konferencija direktora za nacionalno naoružanje ostvaruje realizacijom sledećih zadataka [4]:

- usklađivanje vojnih zahteva za razvoj i proizvodnju naoružanja i vojne opreme unutar NATO;

- unapređenje interoperabilnosti na bojnom polju;

- unapređenje prilika i uslova za transatlantsku saradnju u razvoju i proizvodnji naoružanja i vojne opreme;

- razvoj kritičnih tehnologija odbrane kroz široku tehnološku saradnju zemalja članica NATO i zemalja partnera.

Struktura CNAD koja se bavi poslovima standardizacije radi dostizanja interoperabilnosti, sastoji se od nekoliko organizacionih celina [4].

Glavne grupe CNAD za naoružanje (CNAD Main Armaments Groups) obu- hvataju aktivnosti koje se odnose na razvoj i proizvodnju naoružanja i vojne opreme za ratovanje na kopnu, moru i u vazdušnom prostoru, a to su:

- grupa za naoružanje kopnenih snaga (NATO Army Armaments Group - NAAG, AC/225);

- grupa za naoružanje vazduhoplovnih snaga (NATO Air Force Armaments Group - NAFAG, AC/224);

- grupa za naoružanje mornaričkih snaga (NATO Naval Armaments Group - NNAF, AC/141).

U okviru glavnih grupa CNAD za naoružanje formiraju se privremene radne grupe koje rade na razvoju novih ili reviziji postojećih dokumenata o standardizaciji.

Grupa za naoružanje kopnenih snaga odgovorna je za unapređenje saradnje i standardizacije u oblastima naoružanja i vojne opreme kopnene vojske, realizacijom zajedničkih aktivnosti i razmenom informacija. Radi realizacije navedene funkcije, koordinaciono telo grupe za na- 
oružanje kopnene vojske koordinira radom deset neposredno potčinjenih radnih grupa a to su [6]:

- grupa KoV 2 - oklopna vozila u bliskoj borbi (Land Group 2 on Close Combat Armour),

- grupa KoV 3 - pešadija u bliskoj borbi (Land Group 3 on Close Combat Infantry),

- grupa KoV 4 - zemaljska artiljerija (Land Group 4 on Surface to Surface Artillery),

- grupa KoV 5 - PVO kopnenih trupa (Land Group 5 on Army Air Defense),

- grupa KoV 6 - izviđanje, otkrivanje ciljeva, noćno osmatranje i zaštita od izviđanja - elektronsko ratovanje (Land Group 6 on STANOC-EW),

- grupa KoV 7 - zajednička nuklearno-hemijsko-biološka odbrana (Land Group 7 on Joint NBC Defense),

- grupa KoV 9 - inžinjerijsko uređenje bojnog polja (Land Group 9 on Battlefield Engineering),

- grupa KoV 10 - borbeni helikopteri (Land Group 10 on Battlefield Helicopters),

- tematska grupa 1 - interoperabilnost sistema za modernizaciju opreme vojnika (Topical Group 1 on Soldier System Interoperability),

- tematska grupa 2 - taktičke bespilotne letelice (Topical Group 2 on Tactical UAVs).

Grupa za naoružanje vazduhoplovnih snaga odgovorna je za obezbeđenje saradnje i standardizacije u oblasti vazduhoplovnog naoružanja realizacijom zajedničkih aktivnosti i razmenom informacija. Koordinacioni odbor grupe za naoružanje vazduhoplovnih snaga trenutno koordinira radom sedam neposredno potčinjenih radnih grupa a to su [7]:

- grupa RV 1 - vazduhoplovi sa ljudskom posadom, obuka i simulacija (AIR Group 1 on Manned Aircraft, Training and Simulation),

- grupa RV 2 - vazduhoplovno naoružanje (AIR Group 2 on „Air Weapons“),

- grupa RV 3 - vazduhoplovni aspekti komandovanja i kontrole u uslovima elektronskog ratovanja (AIR Group 3 on ,Air aspects of Command and Control Warfare“),

- grupa RV 4 - vazduhoplovni aspekti obaveštajne delatnosti, nadgledanja i izviđanja (AIR Group 4 on „Air Intelligence, Surveillance and Reconnaissance"),

- grupa RV 5 - avionski sletni sistemi (AIR Group 5 on „Avionics Landing Systems"),

- grupa RV 7 - bespilotne letilice (AIR Group 7 on „Unmanned Aerial Vehicle").

Grupa za naoružanje mornaričkih snaga preko svojih potčinjenih radnih grupa odgovorna je za obezbeđenje saradnje i standardizacije u oblasti mornaričkog naoružanja realizacijom zajedničkih aktivnosti i razmenom informacija. Koordinaciono telo grupe za naoružanje mornaričkih snaga koordinira radom pet neposredno potčinjenih radnih grupa a to su [8]:

- grupa RM 1 - grupa za ratovanje na vodi (NG/1 on Above Water Warfare),

- grupa RM 2 - grupa za ratovanje pod vodom (NG/2 on Undersea Warfare),

- grupa RM 3 - grupa za minsko i protivminsko ratovanje $(\mathrm{NG} / 3$ on Mines and Mine Countermeasures), 
- grupa RM 4 - grupa mornaričke avijacije (NG/4 on Maritime Air),

- grupa RM 6 - grupa za razvoj brodova (NG/6 on Ship Design).

Navedene grupe realizuju aktivnosti standardizacije definisanjem zahteva za standardizaciju i razvojem dokumenata o standardizaciji koja se odnose na razvoj naoružanja i vojne opreme za koje su date grupe nadležne i unapređenjem saradnje između država u istraživanju, razvoju i proizvodnji naoružanja i vojne opreme.

Jedna od CNAD grupa za saradnju (CNAD Cadre Group), koje su zadužene za saradnju u razvoju, proizvodnji i upotrebi naoružanja i vojne opreme je i Grupa za standardizaciju borbene tehnike $i$ tehničke prakse (Group on Standardization of Materiel and Engineering Practices, AC-301) namenjena da obezbedi standardizaciju na polju borbene tehnike $\mathrm{i}$ tehničke prakse (tehničke procedure i postupci koji se koriste prilikom proizvodnje i održavanja borbene tehnike i prilikom vođenja tehničke dokumentacije) [2]. Radi toga grupa za standardizaciju borbene tehnike $i$ tehničke prakse realizuje aktivnosti u sledećim oblastima [2]:

- identifikovanje i razmatranje dokumenata o standardizaciji koji se odnose na standardizaciju borbene tehnike $\mathrm{i}$ tehničke prakse;

- razmatranje međunarodnih standarda koji se odnose na standardizaciju borbene tehnike i tehničke prakse radi njihovog usvajanja i primene na sistem naoružanja i vojne opreme;

- razvoj novih dokumenata o standardizaciji u oblastima gde međunarodni standardi nisu dostupni ili su neadekvatni za primenu na određenim sistemima naoružanja i vojne opreme;

- uspostavljanje saradnje sa ostalim organizacionim celinama NATO radi obezbeđenja koordiniranog pristupa standardizaciji borbene tehnike i tehničke prakse.

Rukovodeće telo Grupe za standardizaciju borbene tehnike i tehničke prakse je Glavna grupa, koja je povezana sa Agencijom NATO za standardizaciju i ostalim organizacionim celinama NATO koje se bave poslovima standardizacije. Glavnu grupu čine visoki predstavnici ministarstava odbrane zemalja članica i zemalja partnera koji su odgovorni za planiranje, implementaciju, nadgledanje i kontrolu poslova koje realizuju radne podgrupe.

Oblasti standardizacije u kojima se angažuju privremeno formirane radne podgrupe su: elektrotehničke - elektronske komponente; materijali; mašinske komponente; vozila; tehnička dokumentacija, procedure i postupci; borbena odeća i oprema; ambalaža; zaštita životne sredine [2].

Na osnovu odluke CNAD-a, u okviru praktičnih mera za implementiranje unapređenog i operativnijeg partnerstva, proširena je saradnja unutar Grupe za standardizaciju borbene tehnike i tehničke prakse sa zemljama partnerima, koje na osnovu toga mogu uzeti učešće u svim radnim podgrupama. Time je obezbeđena tehnička podrška koja će doprineti ostvarenju interoperabilnosti između partnerskih snaga i snaga saveznika [2].

Organizacija NATO za konsultacije, komandovanje i kontrolu (NATO Consultation, Command and Control Organi- 


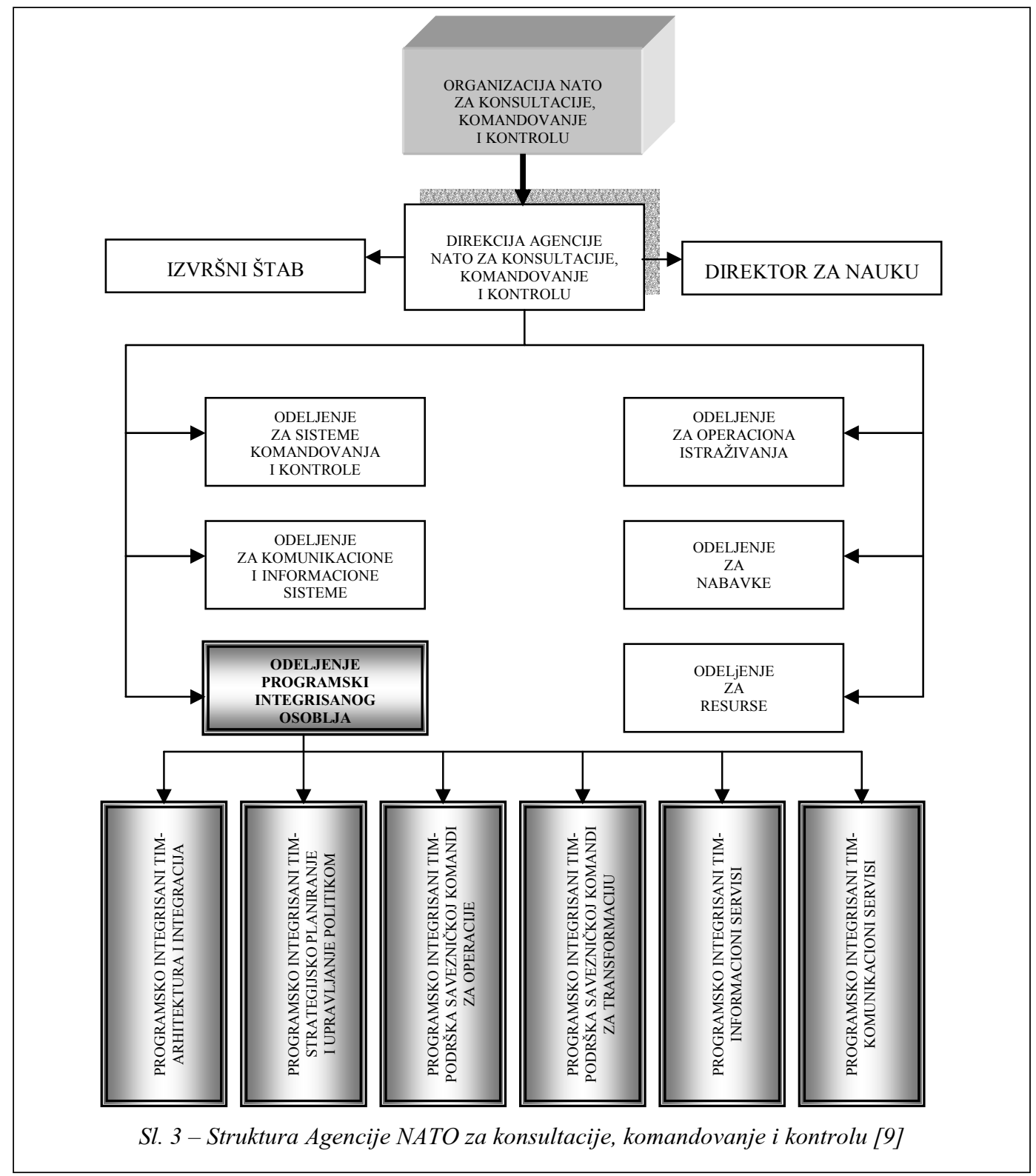

zation - NC3O) formirana je 1996. godine radi obezbeđenja mera za unapređenje rentabilnosti, interoperabilnosti i bezbednosti sistema za konsultacije, komandovanje i kontrolu (C3 sistemi) kao i radi obezbeđenja servisiranja tih sistema [9]. Organizaciono telo Organizacije NATO za konsultaciju, komandovanje i kontrolu koje se bavi aktivnostima standardizacije i obezbeđenjem interoperabilnosti $\mathrm{C} 3$ sistema je Agencija NATO za konsultacije, komandovanje i kontrolu (NATO Consultation, Command and Control Agency $N C 3 A$ ). Ta agencija odgovorna je za raz- 
voj i opremanje NATO sistemima za konsultaciju, komandovanje i kontrolu. Oblasti angažovanja NC3A su [9]:

- politika konsultacija, komandovanja i kontrole - koncept i arhitekture;

- operaciona istraživanja; stemi;

- komunikacioni i informacioni si-

- sistemi za komandovanje i kontrolu;

- poslovi nabavke.

S obzirom na prikazane oblasti angažovanja, NC3A je organizovana u šest odeljenja, to su [9]:

- odeljenje programski integrisanog osoblja (Division of Integrated Programme Staff), koje se bavi pitanjima obezbeđenja standardizacije $\mathrm{i}$ interoperabilosti sistema za konsultacije, komandovanje i kontrolu;

- odeljenje za sisteme komandovanja i kontrole (Division of Command and Control Systems), odeljenje komunikacionih i informacionih sistema (Division of Communication and Information Systems), odeljenje za operaciona istraživanja (Division of Operations Research) i odeljenje za nabavke (Division of Acquisition), koja se bave isključivo poslovima proizvodnje C3 sistema;

- odeljenje za resurse (Division of Resources) koje se bavi poslovima unutrašnje podrške.

Imajući u vidu odgovornosti prikazanih organizacionih celina NC3A, za proces materijalne standardizacije $u$ oblasti komunikacija najznačajnije je odeljenje programski integrisanog osoblja, u čijem radu je moguće i učešće zemalja partnera.

Odeljenje programski integrisanog osoblja sastoji se od šest programski in- tegrisanih timova (Integrated Programme Teams - IPT) [9]:

- arhitektura i integracija (Architecture and Integration - IPT 1),

- strategijsko planiranje i upravljanje politikom (Strategic Planning and Policy Management - IPT 2),

- podrška Savezničkoj komandi za operacije (ACO Support - IPT 3),

- podrška Savezničkoj komandi za transformaciju (ACT Support- IPT 4),

- informacioni servisi (Information Services - IPT 5);

- komunikacioni servisi (Communications Services - IPT 6).

Ovi timovi zaduženi su za ostvarenje sadejstva, koordinacije i integracije, $u$ i van NC3A, radi obezbeđenja standardizacije i dostizanja interoperabilnosti $\mathrm{C} 3$ sistema kroz realizaciju aktivnosti koje se odnose na:

- definisanje zahteva za standardizaciju i razvoj dokumenata o standardizaciji koja se odnose na razvoj sistema za komunikacije;

- unapređenje saradnje između država $u$ istraživanju, razvoju i proizvodnji sistema za komunikacije.

\section{Zaključak}

Standardizacijom materijalnih sredstava unutar NATO razvijaju se i implementiraju dokumenta o standardizaciji koja se tiču karakteristika budućih i/ili sadašnjih materijalih sredstava, kao što su sistemi za komandovanje, kontrolu i komunikaciju, sistemi naoružanja, razni podsistemi, komponente, rezervni delovi i potrošni materijal (uključujući municiju 
i gorivo). Nosioci ove standardizacije unutar NATO su Konferencija direktora za nacionalno naoružanje i Agencija NATO za konsultacije, komandovanje i kontrolu. Ova standardizacija realizuje se na nivou kompatibilnosti za komandno-informacione sisteme i borbenu tehniku, na nivou zamenljivosti za streljačku i artiljerijsku municiju, gorivo i sisteme za snabdevanje i servisiranje multinacionalnih snaga i na nivou zajedništva pri zajedničkom razvoju ratne tehnike. U organizacionim celinama i privremeno formiranim radnim grupama navedenih organizacija učestvuju eksperti iz zemalja članica NATO i zemalja partnera pri izradi novih i revizije postojećih dokumenata o standardizaciji.

Imajući u vidu opredeljenje državne zajednice Srbija i Crna Gora za pristupanje evroatlantskim integracijama, realno je očekivati i njeno buduće učešće u radu organizacionih celina sistema za standardizaciju materijalnih sredstava, ali isto tako i operativnu i administrativnu standardizaciju unutar NATO.

Literatura:

[1] NATO glossary of terms and definitions - AAP-6, NATO Standardization Agency, Brussels, 2003.

[2] Standards for Defence, part I, MOD UK Standardization policy, organizations and implementation, Ministry of Defence United Kingdom, 1999.

[3] Staffing Guide for Allied Joint Publications, Directorate for Operational Plans and Joint Force Development (J-7), Joint Staff, Washington, 2002.

[4] NATO Logistics Handbook, NATO Office of Information and Press, Brussels, 1997.

[5] NATO Handbook, NATO Office of Information and Press, Brussels, 2001.

[6] http://www.nato.int/structur/AC/225/225ENG/naaghome.htm, Veb sajt Grupe za naoružanje kopnenih snaga.

[7] http://www.nato.int/structur/AC/224/home.htm, Veb sajt Grupe za naoružanje vazduhoplovnih snaga.

[8] http://www.nato.int/structur/AC/141/index.htm, Veb sajt Grupe za naoružanje mornaričkih snaga.

[9] http://www.nc3a.nato.int/organization/index.html, Veb sajt Agencije NATO za konsultacije, komandovanje i kontrolu. 


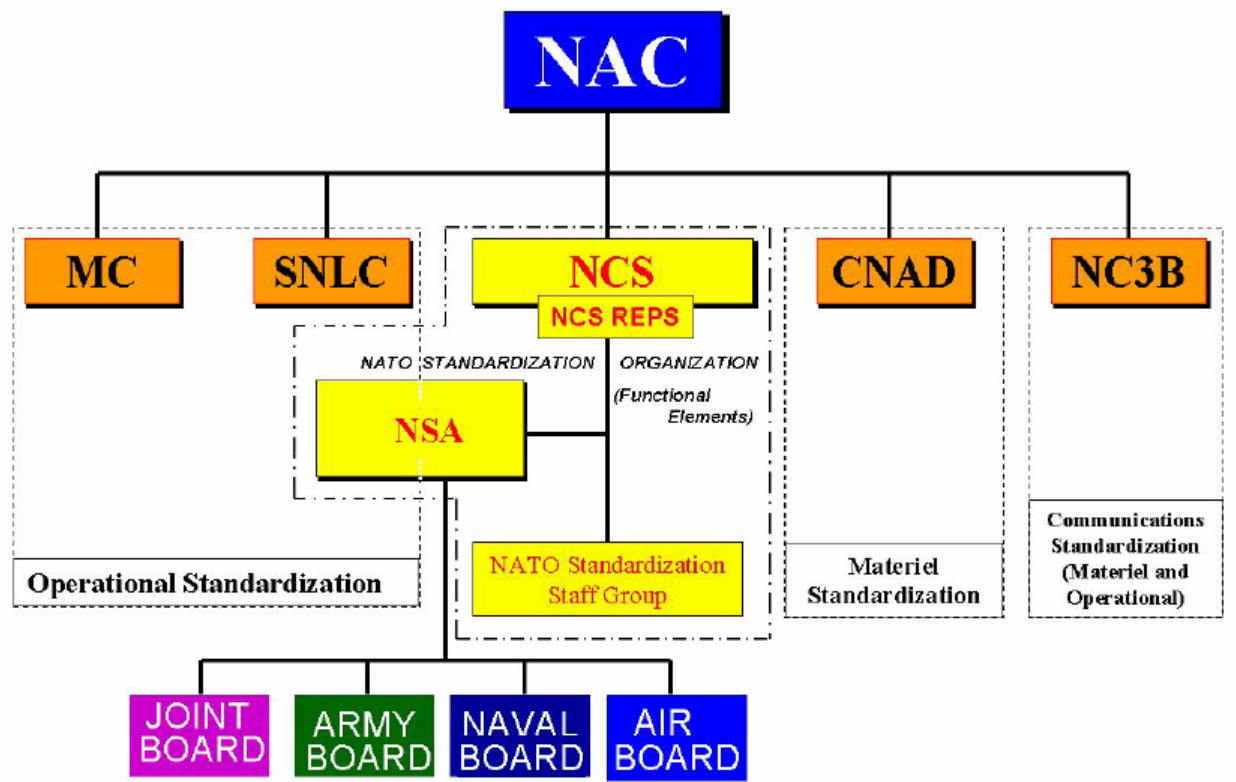

Sl. 1 - Struktura sistema za standardizaciju u NATO:

NAC $=$ North Atlantic Council; $M C=$ Military Committee; $S N L C=$ Senior NATO Logisticians' Conference; NCS = NATO Committee for Standardization; $C N A D=$ Conference of National Armaments Directors; NC3B = NATO Consultation, Command and Control Board; NSA = NATO Standardization Agency

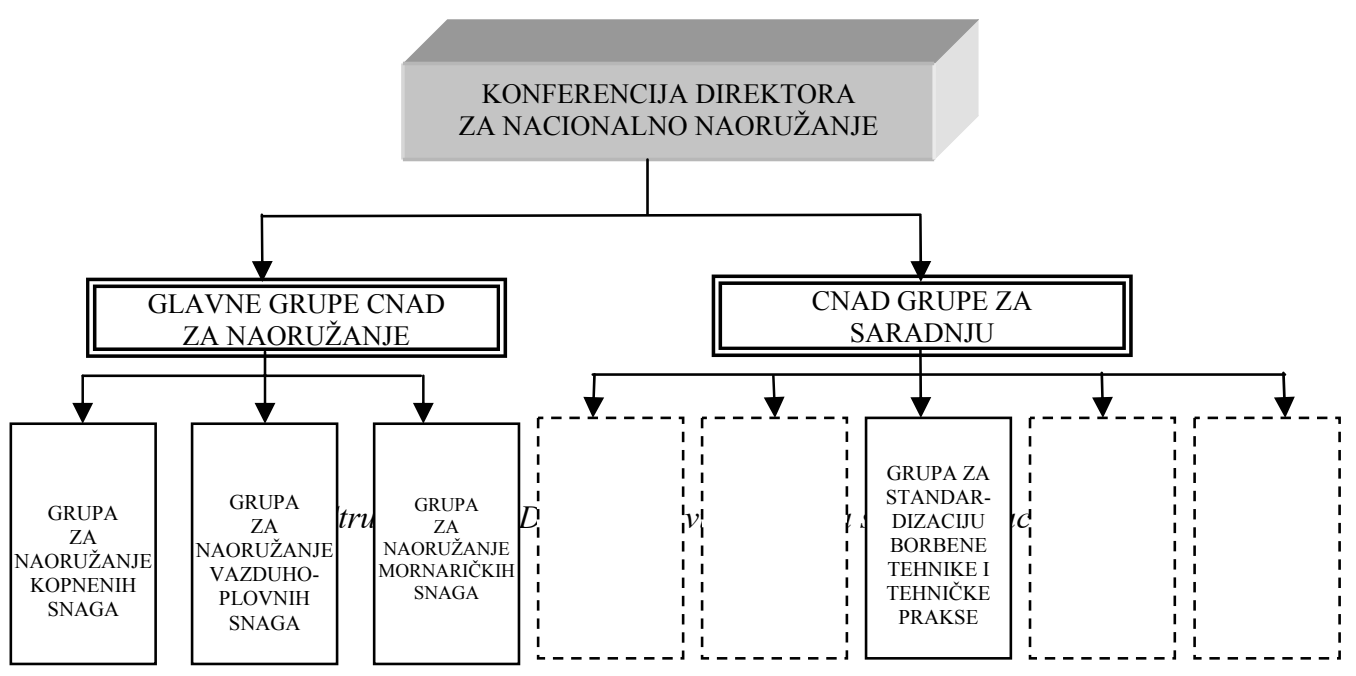




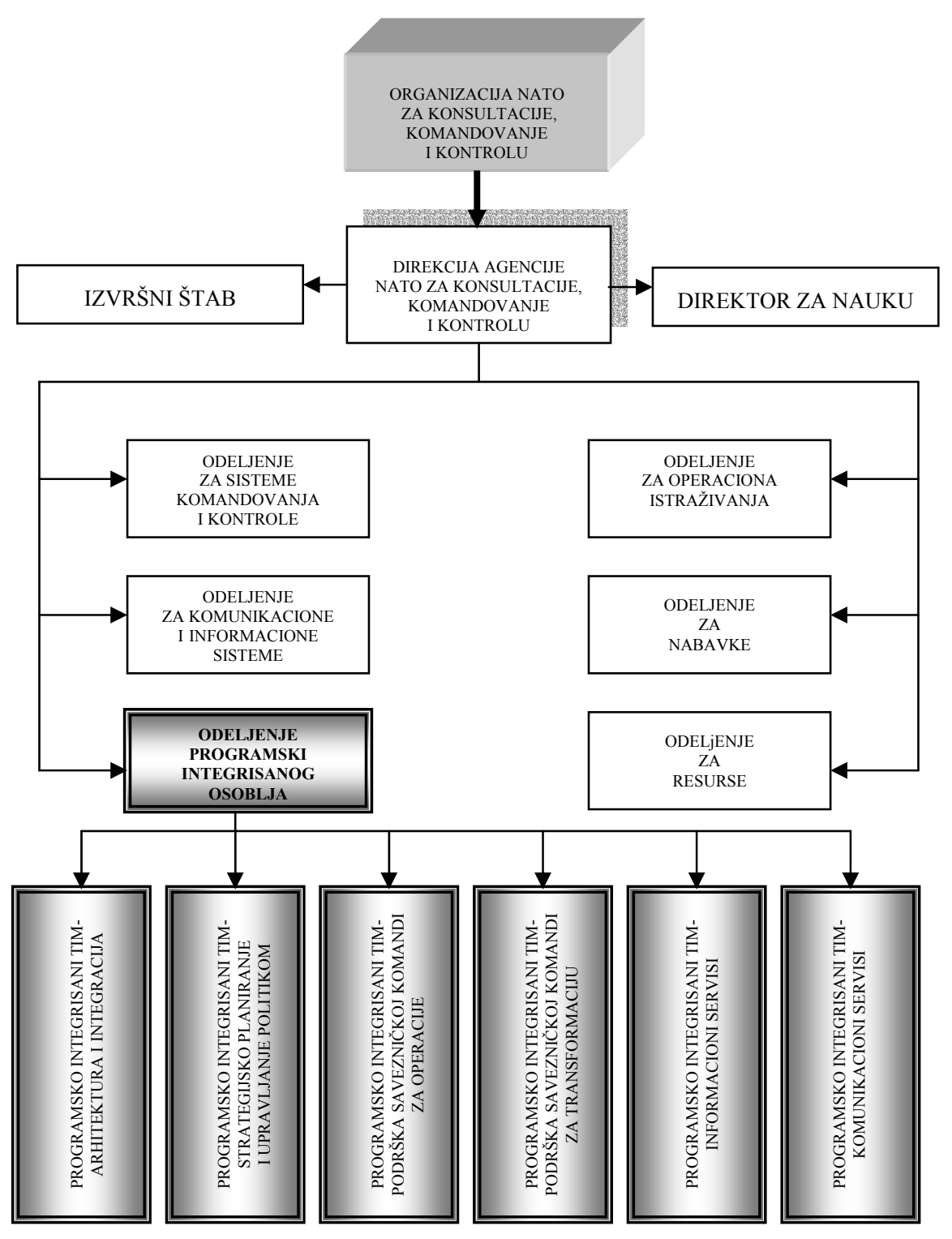


Sl. 3 - Struktura Agencije NATO za konsultacije, komandovanje i kontrolu [9] 